\title{
Nobumichi Shimizu
}

Department of Terrestrial Magnetism, Carnegie Inst., Washington, Washington, D. C. U. S. A.

The ultramafic inclusions of Salt Lake Crater are among the bestdocumented suites of rocks of this kind (Kuno, 1969; Kuno \& Aoki, 1970). Clinopyroxenes separated from 17 samples of spinel lherzolites, olivine eclogites and eclogites (garnet pyroxenites) were analyzed by isotope dilution for $\mathrm{K}, \mathrm{Rb}, \mathrm{Cs}, \mathrm{Sr}$, and $\mathrm{Ba}$ abundances because in lherzolitic and eclogitic assemblages, these elements are most concentrated in clinopyroxene. The trace element variations of clinopyroxenes are considered here in connection with the major element variations in order to understand trace element chemistry in terms of petrologic models. These rocks show wide variations in $\mathrm{Mg} / \mathrm{Fe}$ ratio and other oxide components vary in a systematic manner with respect to this ratio. The $\mathrm{Mg} / \mathrm{Fe} \mathrm{ra}-$ tio should be a good indicator of the upper mantle processes such as partial melting or fractional crystallization. Therefore, the trace element contents of clinopyroxenes are plotted against whole-rock $\mathrm{Mg} / \mathrm{Fe}$ ratio to see if there are any correlations between them (Fig. 1). In lherzolites and olivine eclogites, $\mathrm{K}, \mathrm{Rb}$ and $\mathrm{Cs}$ decrease and $\mathrm{Sr}$ increases with increasing $\mathrm{Mg} / \mathrm{Fe}$ ratio. On the contrary, for eclogites (or garnet pyroxenites) the systematics are rather poor, but they tend to be depleted in these elements relative to the other groups of rocks. It is noticeable that even in sub-ppb level, a trace element (Cs in olivine eclogites) behaves systematically with major elements, indicating that the contamination from the enclosing magma, if any, has been very minor.

Assuming that these rocks represent solid phases which were once equilibrated with liquid either as residues or cumulates, the trace element variations shown in Fig. 1 may be explained by the partition relations of these elements between clinopyroxene and liquid. An important feature in this context is the increase of $\mathrm{Sr}$ with increasing $\mathrm{Mg} / \mathrm{Fe}$ ratio observed in lherzolites and olivine eclogites. If $\mathrm{Mg} / \mathrm{Fe}$ ratio represents the degree of partial melting or stage of fractional crystallization, the increase of $\mathrm{Sr}$ is interpreted as either 1) Sr was more enriched in the residual pyroxene left after larger degree of partial melting or 2) Sr was more enriched in the pyroxene crystallized in the earlier stage of crystallization. These interpretations require that $\mathrm{Sr}$ is partitioned into pyroxene relative to liquid. However, this is quite unlikely in the light of data on Sr partitioning (Philpotts \& Schnetzler, 1970; Shimizu \& Akimoto, 1971). This strongly indicates that the present mineralogy is a recrystallized assemblage and at the time of primary solid-liquid equilibrium there must have been a phase in which Sr was preferentially partitioned. In addition, this phase must have been stable only at higher temperature and have disappeared during the subsolidus recrystallization. A possible candidate for this phase from the trace element point 


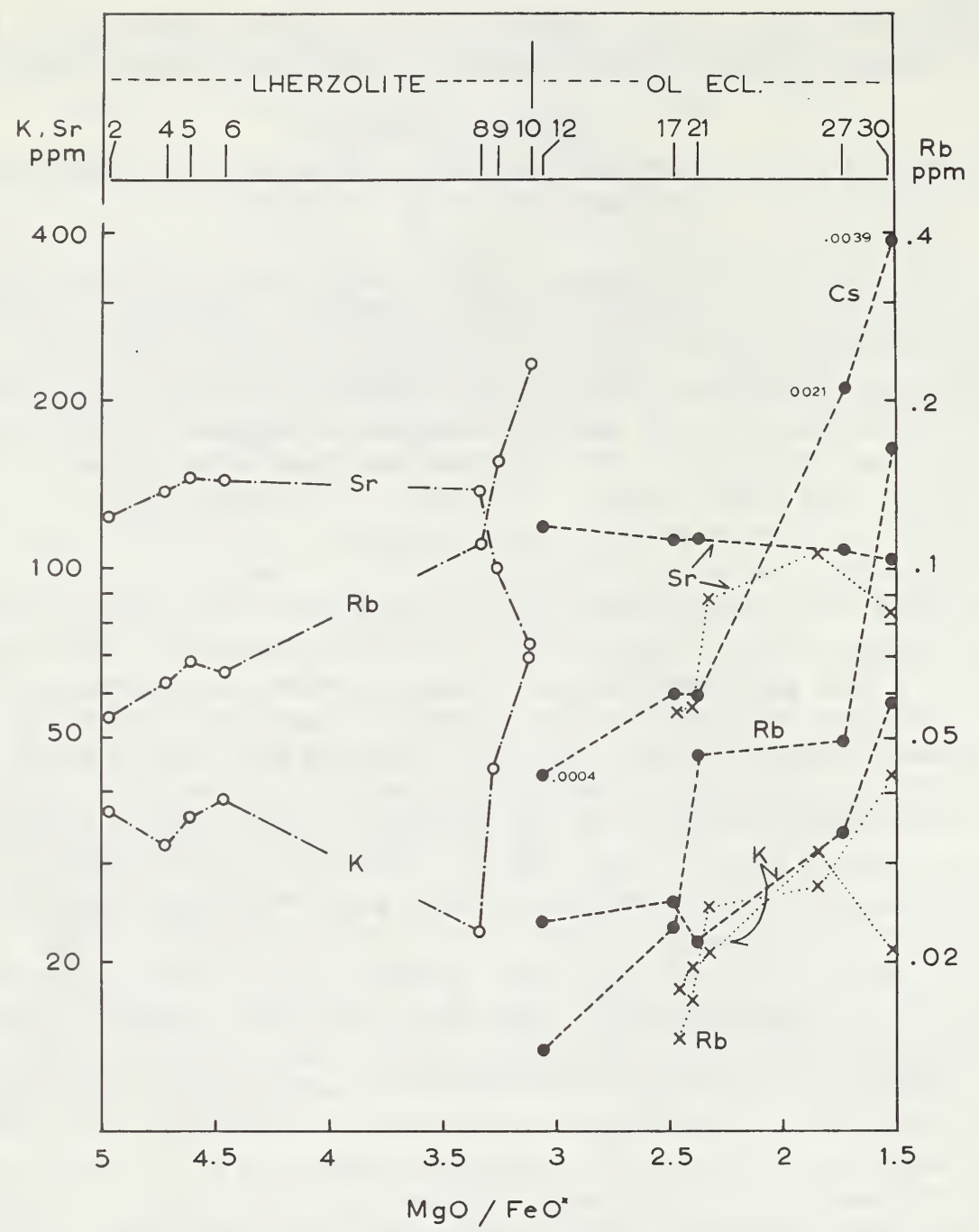

Fig. 1 Trace element variations of clinopyroxenes with respect to whole-rock $\mathrm{MgO} / \Sigma \mathrm{FeO}$. Open circles tied with broken lines: lherzolites; solid circles with dashed lines: olivine eclogites; xs with dotted lines: eclogites.

of view is plagioclase because $\mathrm{Sr}$ is strongly partitioned into plagioclase relative to liquid (Philpotts \& Schnetzler, 1970). The problem is then if this is plausible in the light of phase petrology, since plagioclase is stable only at relatively low pressures and thus puts limitations on the conditions at which these rocks were equilibrated with liquid. There is no way to estimate the $\mathrm{P}$ and $\mathrm{T}$ of the primary equilibrium, but assuming that the subsequent recrystallization took place by isobaric cooling, the estimated $\mathrm{P}$ and $\mathrm{T}$ for the re-equilibrium should be close to the stability limit of plagioclase-bearing assemblages in therzolitic and olivine eclogitic composi- 
tions. The P and $\mathrm{T}$ were then estimated for lherzolites from major element compositions of pyroxenes in the same manner as discussed by Boyd (1973). The temperature was estimated from the diopside composition on the Di-En solvus using the data by Davis \& Boyd (1966), and pressure from alumina content of enstatite using the data by MacGregor (1973). The estimated conditions $\left(10-13 \mathrm{~kb}, 950-1050^{\circ} \mathrm{C}\right)$ are close to the stability limit of plagioclase in lherzolitic composition (Green \& Hibberson, 1970 ) and therefore it seems likely that lherzolites were equilibrated with liquid in the presence of plagioclase and during cooling they crossed the boundary and recrystallized as spinel lherzolite assemblage. The liquid in equilibrium with those rocks may well be tholeiitic rather than alkalic judging from the pressure. Note that the trace element content of the liquid cannot readily be estimated from the pyroxene data, since this is not a primary phase. The same argument appears to hold true for olivine eclogites. Although the olivine eclogites are of intermediate nature between basalt and lherzolite in major elements, the olivine-garnet-pyroxene assemblage may be stable at the conditions given above because of the excess olivine component and higher anorthite content of normative plagioclase of olivine eclogites compared with olivine tholeiite B studied by Green \& Ringwood (1967). In contrast to these two groups of rocks, trace elements of eclogitic pyroxenes appear to be consistent with an argument given by Green (1966) that the eclogites were originally monomineralic clinopyroxene crystallized on the liquidus of alkali basalt at 13 $18 \mathrm{~kb}$ which later exsolved garnet, because when the partition coefficients of these elements between clinopyroxene and liquid obtained at high pressures (Shimizu, in prep.) are applied to the pyroxenes, we obtain trace element contents of the liquid in equilibrium (8000-10000 ppm K; 10-40 ppm Rb; 800 ppm Sr), which are quite reasonable for alkalic basalt.

For a better understanding of upper mantle processes in a possibly different situation from that of Salt Lake Crater, these trace elements were analyzed in clinopyroxenes separated from kimberlite inclusions. They include four garnet therzolites with sheared structure (sheared nodules), three granular garnet lherzolites, one discrete nodule of diopside single crystal, and another discrete nodule of diopside-ilmenite lamellar intergrowth. These samples appear to be separated into two groups in terms of absolute as well as relative abundances of trace elements, one consisting of the sheared and discrete nodules characterized by high $\mathrm{K} / \mathrm{Rb}$ (2000-22000), K/Cs (100000-3000000) K/Ba (50-1100) and K/Sr (1.5-4.5), and almost constant $\mathrm{Sr}$ (around $90 \mathrm{ppm}$ ), while the other being the granular nodules characterized by normal $\mathrm{K} / \mathrm{Rb}$ and $\mathrm{K} / \mathrm{Cs}$, low $\mathrm{K} / \mathrm{Sr}(0.5-0.2$ ) and high Sr (200-500 ppm). Figure 2 shows K-Rb relations. Particularly the anomalously high $\mathrm{K} / \mathrm{Rb}$ in the sheared nodules and high $\mathrm{Sr}$ in the granular ones are extremely hard to reconcile with any pyroxene-silicate melt relationships. $\mathrm{Sr}^{87} / \mathrm{Sr}^{86}$ ratios of most of these pyroxenes are in the range of 0.7027-0.7038, indicating that crustal contamination, if any, is insignificant. These peculiar trace element characteristics suggest that some secondary processes in the mantle, which are not yet understood, have altered the primary features in the pyroxenes. The second- 


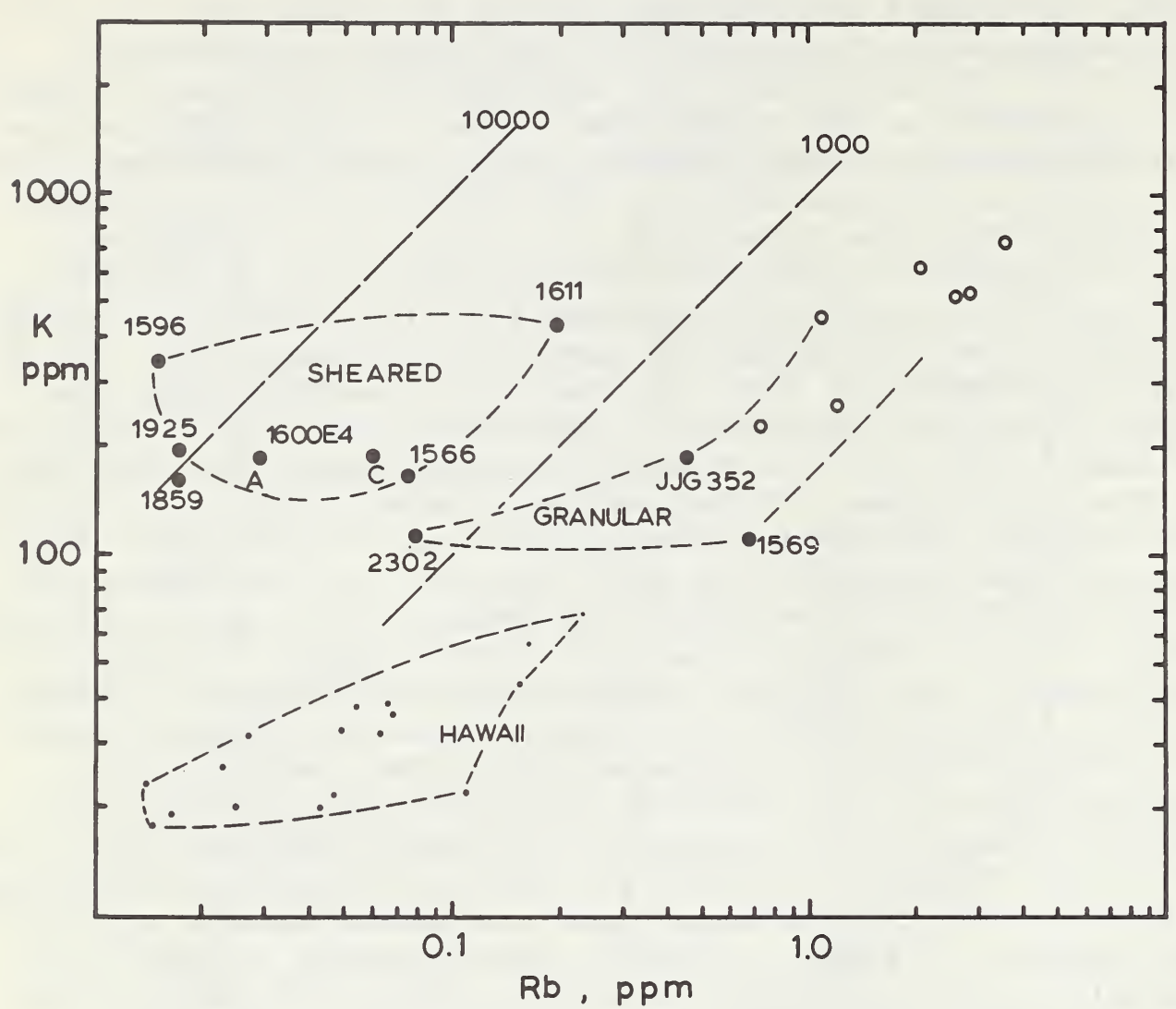

Fig. 2. K-Rb relations of clinopyroxenes from kimberlite inclusions. Solid circles with numbers: present study; open circles: data from literature; dots: clinopyroxenes from Hawaiian inclusions.

ary processes may include reaction between carbonate rich kimberlite magma and/or that between some fluid from which secondary phlogopite was formed.

\section{References}

Boyd, F. R. (1973) Geochim. Cosmochim. Acta, in press.

Davis, B. T. C. \& Boyd, F. R. (1966) J. Geophys. Res. 71, 3567.

Green, D. H. (1966) Earth Planet. Sci. Lett., 1, 414.

Green, D. H. \& Hibberson, W. (1970) Lithos, 3, 209.

Green, D. H. \& Ringwood, A. E. (1967) Geochim. Cosmoch. Acta, 31, 767.

Kuno, H. (1969) Geol. Soc. Am. Mem., 115, 189.

Kuno, H. \& Aoki, K. (1970) Phys. Earth Planet. Int., 3, 273.

MacGregor, I. D. (1973) Am. Mineral., in press.

Philpotts, J. A. \& Schnetzler, C. C. (1970) Geochim. Cosmoch. Acta, $34,307$.

Shimizu, N. \& Akimoto, S. (1971) Earth Planet. Sci. Lett., 13, 134. 